\title{
Pengaruh Total Hutang dan Besarnya Modal Sendiri Terhadap PerolehanEarning per sharePada PT. BFI Finance yang Terdaftar di Bursa Efek Indonesia (BEI) Periode 2007-2016
}

\author{
${ }^{1}$ Susi Artati \\ ${ }^{1}$ Fakultas Ekonomi, Universitas Batanghari Jambi \\ Susiartati30@gmail.com
}

\begin{abstract}
This research aims to find out how the influence of total debt and own capital against the Earning per share simultaneously and partial PT. BFI Finance Tbk 2007-2016 period. This research uses descriptive quantitative methods with multiple linear regression analysis technique. The result of the research shows Fhitung of 8,878 > Ftabel of 4.74 to suggest that the presence of the influence of total debt and own capital against the Earning per share simultaneously, while partially no influence of independent variable i.e. the total debt (X 1) and private equity (X 2) against the Earning per share $(Y)$.
\end{abstract}

Keyword: debt, finance

\section{PENDAHULUAN}

Dalam upaya meningkatkan nilai perusahaan, para pemilik atau pemegang saham menunjuk seorang profesional untuk bekerja atas nama pemegang saham dengan harapan bahwa para manajer tersebut dapat meningkatkan profitabilitas dan nilai perusahaan (Anita:2015) Persaingan bagi perusahaan dapat berpengaruh positif, yaitu menjadi suatu dorongan untuk selalu meningkatkan mutu produk yang dihasilkan, akan tetapi persaingan juga menimbulkan dampak negatif bagi perusahaan, yaitu produk yang dihasilkan akan tergusur dari pasar apabila perusahaan gagal meningkatkan mutu dan kualitas produk yang dihasilkan. (Adisetiawan, 2017)

Total hutang dalam suatu perussahaan merupakan jumlah dari setiap pendanaan yang diperoleh dari luar perusahaan. Perkembangan total hutang pada industri multifinance dapat dilihat pada tabel 1 berikut:

\section{Tabel 1}

Perkembangan Total Hutangpada PT.BFI Finance yang Terdaftar di Bursa Efek Indonesia (BEI) Periode 2007-2016

\begin{tabular}{lrrr}
\hline Tahun & Total Hutang & Perkembangan & \\
\hline 2007 & & 1.321 & - \\
2008 & 2.174 & 64.57229 \\
2009 & 859 & 39412.42 \\
2010 & 1.929 & $99.7754)$ \\
2011 & 2.939 & 52.35874 \\
2012 & 3.71 & 26.23341 \\
2013 & 4.94 & 33.15364 \\
2014 & 6.12 & 23.88664 \\
2015 & 7.75 & 26.63399 \\
2016 & 8.22 & 6.064516 \\
Total & 898.103 & 44487.98 \\
Rata-rata & 89.8103 & 4942.435 \\
\hline Sula
\end{tabular}

Sumber: www.idx.co.iddata diolah 
Pada tabel diatas dapat dilihat perkembangan nilai total hutang periode 2007-2016 berfluktuasi. Perkembangan Total hutang tertinggi yaitu pada tahun 2011 sebesar 52.35874\% dan total hutang terendah pada tahun 2010 sebesar $99.7754 \%$ kearah negatif dan rata-rata perkembangan bernilai4942.435\%. Berikut ini perkembangan modal sendiri pada PT. BFI Finance yang terdaftar di Bursa Efek Indonesia (BEI) periode 2012-2016:

Tabel 2

Perkembangan Modal Sendiripada PT. BFI Financeyang Terdaftar di Bursa Efek Indonesia (BEI) Periode 2007-2016

\begin{tabular}{lrr}
\hline Tahun & Modal Sendiri & \multicolumn{2}{c}{ Perkembangan } \\
\hline 2007 & 1.203 & - \\
2008 & 1.357 & 12.80133 \\
2009 & 1.534 & 13.04348 \\
2010 & 1.941 & 26.53194 \\
2011 & 2.366 & 21.89593 \\
2012 & 188.48 & 7866.188 \\
2013 & 220.673 & 17.08033 \\
2014 & 1067402 & 483603 \\
2015 & 981.723 & $99.908)$ \\
2016 & 1.037 .602 & 105591.9 \\
Total & 2106403.28 & 658485.183 \\
Rata-rata & 210640.328 & 61432.5835 \\
\hline
\end{tabular}

Sumber: www.idx.co.iddata diolah

Pada tabel 2 dapat dilihat perkembangan nilai modal sendiri periode 20072016 berfluktuasi. Modal sendiri tertinggi yaitu pada tahun 2016 sebesar 105591.9\% dan Modal sendiri terendah pada tahun 2015 sebesar $99.908 \%$ dari arah negatif dan rata-rata perkembangan bernilai $61432.5835 \%$. Earning per Share merupakan variabel terikat yang digunakan dalam penelitian ini, yang mana Earning per Share adalah kemampuan lembar saham dalam menghasilkan laba. adapun perkembangan Earning per Share adalah sebagai berikut:

\section{Tabel 3}

Perkembangan Earning Per Sharepada PT. BFI Financeyang Terdaftar di Bursa Efek Indonesia (BEI) Periode 2012-2016

\begin{tabular}{lrr}
\hline Tahun & EPS & Perkembangan \\
\hline 2007 & 263 & - \\
2008 & 305 & 15.96958 \\
2009 & 396 & 29.83607 \\
2010 & 576 & 45.45455 \\
2011 & 559 & $(2.95139)$ \\
2012 & 322 & $(42.3971)$ \\
2013 & 333 & 3.416149 \\
2014 & 97 & $(70.8709)$ \\
2015 & & 21.64948 \\
2016 & 118 & 323.7288 \\
Total & 500 & 323.8485 \\
Rata-rata & 3469 & 0.013304 \\
\hline
\end{tabular}

Sumber: $\underline{w w w . i d x . c o . i d}$

Pada tabel diatas dapat dilihat perkembangan nilai Earning per Share periode 2007-2016 berfluktuasi cenderung menurun. Earning per Share tertinggi 
yaitu pada tahun 2010 sebesar $576 \%$ dan Earning per Share terendah pada tahun 2014 sebesar $97 \%$ rata-rata perkembangan bernilai $0,013 \%$.

Sepanjang pengamatan yang peneliti lakukan memang ada ditemukan satu penelitian yang hampir menyerupai penelitian ini yang pernah dilakukan sebelumnya. Sebagai bahan perbandingan dan acuan peneliti dalam melakukan penelitian ini, maka peneliti menelaah sebuah penelitan yang dilakukan oleh Susanti (2015) membuktikan bahwa variabel hutang jangka pendek diperoleh nilai signifikansi sebesar 0,294 yang menunjukkan bahwa variabel hutang jangka pendek tidak berpengaruh terhadap profitabilitas karena nilai probabilitas lebih besar dari alpha 0,05. Sedangkan variabel hutang jangka panjang dan modal sendiridiperoleh nilai signifikansi sebesar 0,019 dan 0,036menunjukkan bahwa variabel hutang jangka panjang dan modal sendiri berpengaruh terhadap profitabilitas karena memiliki nilai probabilitas lebih kecil dari 0,05.

Berdasarkan rumusan masalah diatas dapat dilihat bahwa tujuan penelitian ini adalah sebagai berikut: 1) Untuk mengetahui bagaimana pengaruh total hutang dan modal sendiri terhadap Earning per sharesecara simultan dan parsial pada PT. BFI Financeyang terdaftar pada BEI Periode 2007-2016; 2) Untuk mengetahui sejauh manavariabel total hutang dan modal sendiri mempengaruhi Earning per sharepada PT. BFI Financeyang terdaftar pada BEI Periode 2007-2016.

\section{Landasan Teori}

Manajemen merupakan suatu proses kerja sama dengan dua orang atau lebih untuk mencapai tujuan organisasi dengan melakukan perencanaan, pengorganisasian, pengarahan, pengkoordinasian dan pengendalian untuk mencapai tujuan organisasi efektif dan efisien dengan menggunakan sumber daya manusia dan sumber daya lainnya (Effendi, 2014: 5).

Manajemen Keuangan menurut Fahmi (2014:2) merupakan penggabungan dari ilmu dan seni yang membahas, mengkaji, menganalisis tentang bagaimana seorang manajer keuangan dengan mengolah dana dan membagi dana dengan tujuan mampu memberikan profit atau kemakmuran bagi pemegang saham dan sustainability (keberlanjutan) usaha bagi perusahaan.

Menurut Fahmi (2014: 21) laporan keuangan adalah suatu informasi yang menggambarkan kondisi keuangan suatu perusahaan, dan lebih jauh informasi tersebut dapat dijadikan sebagai gambaran kinerja keuangan perusahaan tersebut. Menurut Fahmi (2014: 29) neraca merupakan informasi yang menggambarkan tentang kondisi dan situasi aktiva lancar, aktiva tetap, modal sendiri dan hutang serta berbagai item lainnya yang termasuk di sana, untuk selanjutnya informasi tersebut dijadikan sebagai alat dalam mendukung proses pengambilan keputusan.

Neraca melaporkan aset, kewajiban, dan ekuitas pemegang saham pada suatu tanggal-tanggal tertentu. Dengan menyediakan informasi mengenai aset, kewajiban dan ekuitas, neraca dapat dijadikan sebagai dasar-dasar untuk mengevaluasi tingkat likuiditas, struktur modal dan efesiensi perusahaan, serta menghitung tingkat pengembalian aset atas laba bersih (Hery, 2015: 64-65).

\section{Laporan Laba/Rugi}

Menurut Hery (2015: 34) laporan laba rugi adalah laporan yang menyajikan ukuran keberhasilan operasi perusahaan selama periode waktu tertentu. Lewat laporan laba-rugi, dapat diketahui besarnya tingkat profitabilitas yang dihasilkan. Lewat laporan laba-rugi, kreditur mempertimbangan kelayakan kredit debitur. Penetapan pajak yang nantinya akan disetorkan ke kas negara juga diperoleh 
berdasarkan jumlah laba bersih yang ditunjukkan lewat laporan laba-rugi. Menurut Fahmi (2014: 60) hutang adalah saldo kredit atau jumlah yang harus dipindahkan dari saat tutup buku ke periode tahun beriutnya berdasarkan pencatatan yang sesuai dengan prinsip akuntansi (saldo kredit bukan akibat saldo negatif aktiva

Menurut Riyanto (2011:240) modal sendiri (equity capital) merupakan dana jangka panjang yang disediakan oleh perusahaan (pemegang saham), yang terdiri dari berbagai jenis saham (saham preferen atau saham biasa), serta laba ditahan. Modal sendiri pada dasarnya adalah modal yang berasal dari pemilik perusahaan dan tertanam dalam perusahaan untuk waktu yang tidak tertentu lamanya. Modal sendiri yang berasal dari sumber intern adalah modal dalam bentuk keuntungan yang dihasilkan perusahaan, dapat dirumuskan sebagai berikut:

Modal sendiri $=$ Total modal sendiri

\section{Earning per share (EPS)}

Syafri, 2008 Earning per share ialah rasio yang menunjukkan seberapa besar kemampuan perlembar saham didalam menghasilkan laba. Syamsuddin, 2009 Earning per share ialah rasio yang menggambarkan jumlah rupiah yang diperoleh pada setiap lembar saham biasa. Oleh Sebab itu pada umumnya manajemen perusahaan, pemegang saham biasa dan juga calon pemegang saham sangat tertarik akan earning per share. Earning per share ialah suatu indikator keberhasilan suatu perusahaan.

$E P S=\frac{\text { laba bersih sebelum pajak }- \text { deviden sahan preferen }}{\text { jumlah saham beredar }}$

\section{Hubungan Antar Variabel}

Menurut Tandelilin (2010) pengukuran kinerja perusahaan menggunakan analisis rasio keuangan sangat penting karena apabila dari analisis rasio keuangan menunjukkan rasio keuangan yang baik maka mencerminkan kinerja yang baik pula. Hal ini akan meningkatkan laba bersih perusahaan.Dengan demikian, rasio yang digunakan dalam variabel kinerja perusahaan adalah rasio yang diukur dengan indikator total hutang dan modal sendiri.

\section{Pengaruh Total Utang Terhadap Earning per share}

Menurut M. Nafarin (2013:334) hubungan total utang dengan laba bersih adalah dengan menambah utang jangka pendek dan utang jangka panjang dan modal sendiri dimaksudkan untuk ekspansi, yaitu memperluas kegiatan perusahaan, memperluas kegiatan produksi, memperluas kegiatan pemasaran dengan tujuan memperoleh laba sebesar-besarnya. Dengan peningkatan kegiatan produksi dan pemasaran (ekspansi) sebagai akibat peningkatan pembelanjaan dengan utang dan modal sendiri dapat memperbesar perolehan harga selembar saham.

\section{Pengaruh Modal Kerja Terhadap Earning per share}

Modal kerja adalah modal sendiri adalah modal yang berasal dari pemilik perusahaan dan yang tertanam di dalam perusahaan untuk jangka waktu yang tidak ditentukan lamanya.Keuntungan menggunakan modal sendiri untuk membiayai suatu usaha adalah tidak adanya beban biaya bunga maupun biaya administrasi, tidak tergantung pada pihak lain, tanpa memerlukan persyaratan yang rumit, serta tidak ada keharusan dalam pengembalian modal, namun penggunaan modal sendiri jumlahnya sangat terbatas. Berdasarkan teori yang ada menurut Kasmir (2015:256) bahwa tujuan manajemen modal kerja bagi 
perusahaan guna untuk memaksimalkan penggunaan aktiva lancar guna meningkatkan penjualan dan laba.Sehingga disini dapat kita hubungkan antara modal sendiri dengan Earning per share sebagai imbalan hasil dari modal terhadap lembar saham untuk mendapatkan laba.

\section{Hipotesis}

Berdasarkan rumusan masalah yang telah di kemukakan diatas maka dapat dibuat hipotesis sebagai berikut:

1. Diduga total hutang dan modal sendiri berpengaruh secara simultan terhadap laba bersih pada industri multifinance yang terdaftar di Bursa Efek Indonesa (BEI) periode 2012-2016.

2. Diduga total hutang dan modal sendiri berpengaruh secara parsial terhadap laba bersih pada industri multifinance yang terdaftar di Bursa Efek Indonesa (BEI) periode 2012-2016.

\section{METODE}

Metode analisis data yang digunakan dalam penelitian ini adalah :

a. Metode deskriptif kualitatif

Metode deskriptif kualitatif adalah metode yang digunakan untuk menganalisis data keuangan perusahaan dengan cara membandingkan antara teori dan konsep yang ada serta hasil penelitian terdahulu terhadap masalah yang dihadapi perusahaan. (Istijanto, 2009:45)

b. Metode deskriptif kuantatif

Metode deskriptif kuanitatif adalah metode yang digunakan untuk menganalisis data keuangan perusahaan dengan jalan membandingkan laba rugi perusahaan serta menghitung tendensi perubahan yang terjadi. (Istijanto, 2009:46).

\section{Metode Pengumpulan Data}

Dalam rangka memperoleh data yang diperlukan, teknik pengumpulan data sekunder adalah sebagai berikut:

1. Riset kepustakaan

Teknik pengumpulan data yang didasarkan pada teori-teori dari berbagai literatur yang berhubungan dengan obyek penelitian. Data yang diperlukan untuk penelitian ini diperoleh dari buku-buku yang berhubungan dengan penelitian yang akan dilakukan. Data yang dibutuhkan dapat juga diambil dari internet sebagai salah satu media riset kepustakaan.

2. Dokumentasi

Teknik pengumpulan data yang dilakukan dengan cara mencatat data dari dokumen yang berkaitan dengan obyek penelitian dari website resmi. Data tersebut berupa laporan keuangan yang diterbitkan setiap tahun oleh website Bursa Efek Indonesia yaitu www.idx.co.id.

\section{Uji Asumsi Klasik}

Sebelum melakukan uji hipotesis maka terlebih dahulu dilakukan uji asumsi klasik, yaitu:

a. Uji Normalitas

Uji normalitas bertujuan untuk menguji apakah dalam modelregresi, variabel dependen dan variabel independen mempunyai distribusidata normal atau tidak dengan menggunakan Normal P-Plot. Model regresi yang baik adalah mempunyai distribusi normal atau mendekati normal. Uji normalitas dilakukan 
dengan analisa grafik, dengan dasar pengambilan keputusan adalah sebagai berikut:

- Jika data menyebar di sekitar garis diagonal dan mengikuti arah garisdiagonalnya, maka model regresi memenuhi asumsi normalitas.

- Jika data menyebar jauh dari garis diagonal dan/atau tidak mengikutiarah garis diagonal, maka model regresi tidak memenuhi asumsinormalitas.

b. Uji Multikoliniearitas

Uji multikoliniearitas bertujuan untuk menguji apakah dalam model regresi ditemukan adanya korelasi antar variabel independen (Ghozali, 2005:91). Jika terjadi korelasi, maka terdapat problem multikoliniearitas. Model regresi yang baik seharusnya tidak terjadi korelasi diantara variabel independennya. Ada tidaknya multikoliniearitas di dalam model regresi adalah dilihat dari besaran VIF (Variance Inflation Factor) dan tolerance. Regresi yang terbebas dari problem multikolinearitas apabila nilai VIF $<10$ dan nilai tolerance $>0,10$, maka data tersebut tidak ada multikolinearitas (Ghozali, 2005:92).

c. Uji Autokorelasi

Uji autokorelasi bertujuan menguji apakah dalam sebuah model regresi linear ada korelasi antara kesalahan pengganggu pada periode dengan kesalahan pada periode t-1 (sebelumnya). Auto korelasi digunakan pada model regresi yang datanya time series (Ghozali, 2005:96). Jika terjadi korelasi, maka ada problem autokorelasi. Untuk mendeteksi ada tidaknya autokorelasi perlu digunakan uji Durbin-Waston, dimana hipotesis yang akan diuji adalah:

- Angka D-W di bawah -2, berarti ada autokorelasi positif.

- Angka D-W di antara -2 sampai +2, berarti tidak ada autokorelasi.

- Angka D-W di atas +2 , berarti autokorelasi negatif.

d. Uji Heteroskedastisitas

Menurut Priyanto (2009:160) heteroskedastisitas adalah varian residual yang tidak sama dengan pengamatan didalam model regresi. Regresi yang baik seharusnya tidak terjadi Heteroskedastisitas. Heteroskedastisitas dalam penelitian ini diuji dengan menggunakan uji scatterplot. Ada atau tidaknya heteroskedastisitas dapat dilakukan dengan melihat ada atau tidaknya pola tertentu pada grafik scatterplot antara SRESID dan ZPRED dimana sumbu Y adalah yang diprediksi dan sumbu $\mathrm{X}$ adalah residual. Jika ada pola tertentu, seperti titik-titik yang ada membentuk pola tertentu (bergelombang, melebar kemudian menyempit) maka mengindikasikan telah terjadi heteroskedastisitas. Jika tidak ada pola yang teleh dan titik menyebar di atas dan di bawah angka 0 maka tidak terjadi heteroskedastisitas.

\section{Analisis Regresi Linear Berganda}

Untuk mengetahui apakah rasio keuangan berpengaruh terhadap laba bersih dan seberapa besar pengaruhnya maka digunakan analisis regresi linear berganda, adapun persamaan dari regresi linear berganda dalam penelitian ini adalah sebagai berikut:

$\mathbf{Y}=\mathbf{a}+\mathbf{b}_{1} \mathbf{x}_{1}+\mathbf{b}_{2} \mathbf{x}_{2}+\mathbf{e}$

Dimana: $\mathrm{Y}=$ Earning per share; $\mathrm{X}_{1}=$ Total Hutang; $\mathrm{X}_{2}=$ Modal sendiri; = Konstanta; $\mathrm{b}=$ koefisien regresi; $\mathrm{e} \quad=$ error

\section{Uji F}


Digunakan untuk menguji keberartian pengaruh dari seluruh variabel dependen secara bersama-sama terhadap variabel independen.Hipotesis ini dirumuskan sebagai berikut:

$\mathrm{H}_{0}=$ tidak ada pengaruh signifikan dari variabel independen secara simultan terhadap variabel dependen.

$\mathrm{H}_{\mathrm{a}}=$ ada pengaruh dari variabel independen secara simultan terhadap variabel dependen.

Kriteria pengujiannya sebagai berikut:

Jika $\mathrm{F}_{\text {hitung }}>\mathrm{F}_{\text {tabel }}$ maka $\mathrm{H}_{\mathrm{o}}$ ditolak dan $\mathrm{H}_{\mathrm{a}}$ diterima

Jika $\mathrm{F}_{\text {hitung }}<\mathrm{F}_{\text {tabel }}$ maka $\mathrm{H}_{\mathrm{o}}$ diterima dan $\mathrm{H}_{\mathrm{a}}$ ditolak

\section{Uji t}

Uji keberartian koefisien (bi) dilakukan dengan statistik-t. Hal ini dilakukan untuk menguji koefisien regresi secara parsial dari variabel independennya.

Adapun hipotesis yang dilakukan sebagai berikut:

$\mathrm{H}_{\mathrm{o}}=$ tidak ada pengaruh signifikan dari variabel independen secara parsial terhadap variabel dependen.

$\mathrm{H}_{\mathrm{a}}=$ ada pengaruh dari variabel independen secara parsial terhadap variabel dependen.

Kriteria pengujiannya sebagai berikut:

Jika $t_{\text {hitung }}>\mathrm{t}_{\text {tabel }}$ maka $\mathrm{H}_{\mathrm{o}}$ ditolak dan $\mathrm{H}_{\mathrm{a}}$ diterima

Jika $\mathrm{t}_{\text {hitung }}<\mathrm{t}_{\text {tabel }}$ maka $\mathrm{H}_{\mathrm{o}}$ diterima dan $\mathrm{H}_{\mathrm{a}}$ ditolak

\section{HASIL}

\section{Uji Heteroskedasitas}

Dasar uji heterskedasitas yakni: (1) jika ada pola tertentu, yang teratur (bergelombang, melebar, kemudian menyempit), maka mengindikasikan telah terjadi heteroskedasitas, (2) jika ada dibawah angka nol pada sumbu Y, maka mengindikasikan tidak terjadi heteroskedasitas. Hasil uji heteroskodasitas dapat dilihat pada grafik scatterplot berikut ini:

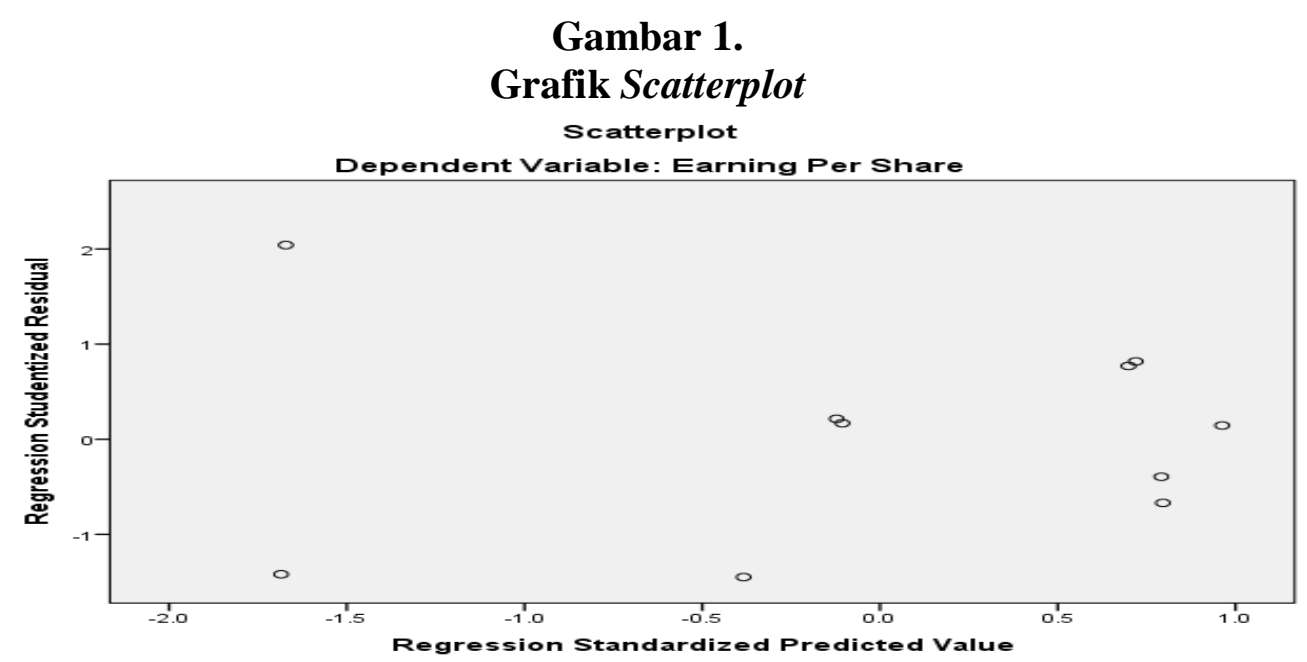

Grafik scatterplot tersebut dapat kita lihat bahwa titik-titik menyebar secara acak serta tidak membentuk pola tertentu atau tidak teratur. Hal ini mengindikasikann tidak terjadinya heteroskedasitas pada model regresi sehingga model ini layak di pakai. 


\section{Uji Normalitas}

Hasil uji normalitas dengan grafik histograf dan normal probability plot ditunjukkan sebagai berikut :

\section{Gambar 2.}

\section{Uji Normalitas}

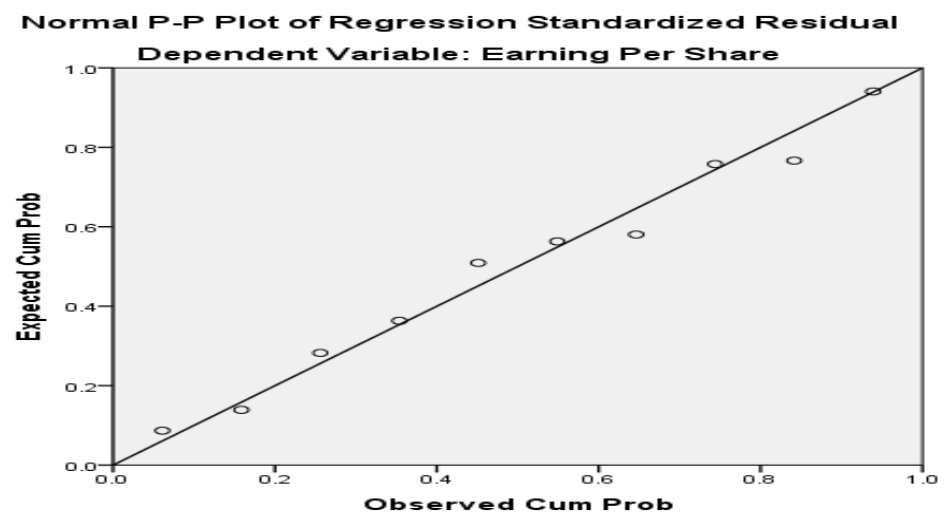

Berdasarkan hasil uji normalitas, dapat dilihat dari Gambar 2 diatas (Normal P-Plot of Regression Standardized Residual) terlihat bahwa titik-titik menyebar di sekitar garis diagonal, serta penyebarannya mengikuti garis diagonal. Hal ini menunjukan bahwa model regresi layak dipakai karena memenuhi asumsi normalitas data berdistribusi normal, karena titik dalam gambar menyebar di sekitar garis diagonal dan arahnya mengikuti garis diagonal.

\section{Uji Multikolineritas}

Multikolinearitas merupakan fenomena adanya korelasi yang sempurna antara satu variabel bebas dalam suatu model regresi linear berganda. Uji ini dilakukan dengan menggunakan VIF dengan kriteria, jika VIF suatu variabel bebas > 10, maka dapat disimpulkan bahwa variabel bebas tersebut terjadi multikolinearitas. Berdasarkan hasil analisis regresi linear berganda yang telah dilakukan, ternyata diperoleh nilai VIF masing-masing variabel bebas sebagai berikut :

\section{Tabel 4}

\section{Uji Multikolinearitas}

\section{Coefficients $^{\mathrm{a}}$}

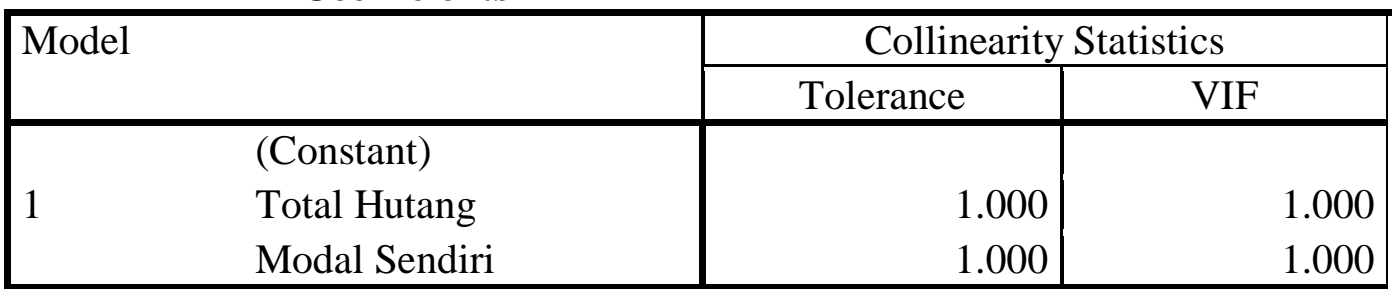

Sumber : Data Diolah

Hasil peneitian pada tabel 4 menunjukan bahwa semua variabel independen yang memiliki nilai VIF kurang dari 10 yaitu 1,000. Sehingga Oleh karena itu dapat disimpulkan bahwa tidak terjadi multikolinearitas antara variabel independen dalam model regresi. 


\section{Uji Autokorelasi}

Persamaan regresi yang baik adalah yang tidak memiliki masalah autokorelasi jika terjadi autokorelasi maka persamaan tersebut menjadi tidak baik atau tidak layak di pakai prediksi. Masalah autokorelasi baru timbul jika ada korelasi secara linear antara kesalahan pengganggu periode t (berada) dengan kesalahan pengganggu periode $\mathrm{t}$ (sebelumnya). Dengan demikian dapat dikatakan bahwa uji asumsi klasik autokorelasi di lakukan untuk data time series atau data yang mempunyai seri waktu, misalnya data dari tahun 2007-2016. Dapat kita lihat dalam Tabel 5 berikut :

\section{Tabel 5 \\ Uji Autokorelasi \\ Model Summary ${ }^{b}$}

\begin{tabular}{|l|r|r|r|r|}
\hline Model & R & R Square & Adjusted R Square & Durbin-Watson \\
\cline { 5 - 6 } & & & & \\
\hline 1 & $.448^{\mathrm{a}}$ & .201 & -.028 & 1.607 \\
\hline
\end{tabular}

Sumber: Data Diolah

Berdasarkan hasil perhitungan analisis data dengan menggunakan SPSS versi 20 diperoleh hasil uji autokorelasi seperti tabel 5. dari tabel tersebut dapat dilihat angka Durbin-Watson Test sebesar 1,617. Karena angka D-W test 1,917 terletak diantara -2 dan +2 , maka diambil keputusan bahwa model regresi ini tidak ada autokorelasi. Sehingga dapat dilakukan model regresi dalam penelitian ini layak untuk memprediksi besarnya laba bersih.

\section{Analisis Regresi Berganda}

Pengelolaan data menggunakan software SPSS versi 20 dengan menggunakan data dari laporan keuangan perusahaan dari tahun 2007-2016. Hasil pengelolaan tersebut dapat dilihat pada tabel berikut:

\section{Tabel 6}

\section{Tabel Regresi Linear Berganda}

\section{Coefficients $^{\mathrm{a}}$}

\begin{tabular}{|rl|r|r|r|}
\hline \multicolumn{2}{|l|}{ Model } & \multicolumn{2}{|c|}{ Unstandardized Coefficients } & \multicolumn{1}{c|}{$\begin{array}{c}\text { Standardized } \\
\text { Coefficients }\end{array}$} \\
\cline { 3 - 5 } & & B & \multicolumn{1}{c|}{ Std. Error } & \multicolumn{1}{c|}{ Beta } \\
\hline \multirow{2}{*}{1} & (Constant) & 2.577 & .146 & .027 \\
& Total Hutang & .009 & .113 & -.447 \\
\hline
\end{tabular}

Hasil pengelolaan data maka didapatkan nilai-nilai koefisien seperti pada tabel diatas. Dari nilai-nilai koefisien tersebut didapatkan persamaan regresi linear sebagai berikut:

$\mathrm{Y}=2,577+0,009 \mathrm{TH}-0,050 \mathrm{MS}+\mathrm{e}$

Berdasarkan persamaan regresi linear berganda di atas dapat di interpretasikan sebagai berikut :

1. Nilai Konstan sebesar 2,577 memberikan arti bahwa apabila total hutang $\left(\mathrm{X}_{1}\right)$ dan modal sendiri $\left(\mathrm{X}_{2}\right)$ di asumsikan $=0$, maka Earning Per Share $(\mathrm{Y})$ secara konstan bernilai 2,577. 
2. Nilai Koefisien regresi variabel total hutang $\left(X_{1}\right)$ sebesar 0,009 memberikan arti bahwa total hutang $\left(\mathrm{X}_{1}\right)$ berpengaruh negatif terhadap Earning Per Share. Hal ini Menunjukkan jika total hutang $\left(\mathrm{X}_{1}\right)$ meningkat sebesar $1 \%$, maka Earning Per Share akan naik sebesar 0,009\%.

3. Nilai Koefisien regresi variabel Modal sendiri $\left(\mathrm{X}_{2}\right)$ sebesar $-0,050$ memberikan arti bahwa Modal sendiri $\left(\mathrm{X}_{2}\right)$ berpengaruh negatif terhadap Earning Per Share. Hal ini menunjukkan jika Modal sendiri $\left(\mathrm{X}_{2}\right)$ menurun sebesar $1 \%$, maka Earning Per Share akan turun sebesar 0,050\%.

\section{Uji F}

Uji statistik $\mathrm{F}$ pada dasarnya menunjukkan apakah semua variabel independen yang dimasukkan dalam model mempunyai pengaruh secara bersamasama/ simultan terhadap variabel dependen. Yaitu; Total hutang $\left(\mathrm{X}_{1}\right)$ dan modal sendiri $\left(\mathrm{X}_{2}\right)$ secara simultan terhadap Earning Per Share $(\mathrm{Y})$ pada PT. BFI Finance yang terdaftar di Bursa Efek Indonesia (BEI) periode 2007-2016.

Berikut ini hasil Uji F yang diolah menggunakan SPSS 20 disajikan dalam tabel berikut ini :

Tabel 7

Tabel Uji Simultan (Uji F)

\begin{tabular}{|ll|l|l|l|l|l|}
\hline \multicolumn{2}{|c|}{ Model } & $\begin{array}{l}\text { Sum of } \\
\text { Squares }\end{array}$ & df & $\begin{array}{l}\text { Mean } \\
\text { Square }\end{array}$ & F & Sig. \\
\hline \multirow{2}{*}{1} & Regression & .126 & 2 & .063 & .878 & $.457^{\mathrm{b}}$ \\
& Residual & .502 & 7 & .072 & & \\
& Total & .628 & 9 & & & \\
\hline
\end{tabular}

Kriteria pengujian secara simultan (Uji $\mathrm{F}$ ) dengan membandingkan $\mathrm{F}$ hitung denganF tabel pada taraf signifikan $\alpha=0,05$. Jumlah data pembentukan regresi 10 , maka Df $1=\mathrm{k}-1=3-1=2$ sedangkan $\mathrm{df} 2=\mathrm{n}-\mathrm{k}=10-3=7$, maka nilai $\mathrm{F}_{\text {tabel }}$ sebesar 4,74. Dengan demikian $F$ hitung sebesar 8.878> $F$ tabel sebesar4,74 sehingga $H_{o}$ ditolak dan $\mathrm{H}_{\mathrm{a}}$ diterima artinya terdapat pengaruh signifikan variabel antara variabel total hutang $\left(\mathrm{X}_{1}\right)$ dan modal sendiri $\left(\mathrm{X}_{2}\right)$ secara simultan terhadap total Earning Per Share (Y) PT. BFI Financeyang terdaftar di Bursa Efek Indonesia (BEI) Periode 2007-2016.

\section{Uji $t$}

Uji parsial (uji t) digunakan untuk mengetahui apakah model persamaan regresi telah signifikan untuk digunkan mengukur pengaruh secara parsial variabel bebas total hutang $\left(\mathrm{X}_{1}\right)$ dan modal sendiri $\left(\mathrm{X}_{2}\right)$ terhadap Earning Per Share (Y). Dari hasil pengolahan data dengan menggunakan program SPSS 20 diperoleh hasil uji t sebagai berikut:

Tabel 8

Tabel Uji Parsial (Uji t)

\begin{tabular}{|c|c|c|c|c|c|c|}
\hline \multirow{2}{*}{\multicolumn{2}{|c|}{ Model }} & \multicolumn{2}{|c|}{$\begin{array}{c}\text { Unstandardized } \\
\text { Coefficients } \\
\end{array}$} & $\begin{array}{c}\text { Standardized } \\
\text { Coefficients }\end{array}$ & \multirow[t]{2}{*}{$\mathrm{t}$} & \multirow[t]{2}{*}{ Sig. } \\
\hline & & $\mathrm{B}$ & Std. Error & Beta & & \\
\hline \multirow{2}{*}{1} & (Constant) & 2.577 & .146 & & $\begin{array}{r}17.61 \\
4\end{array}$ & .000 \\
\hline & Total Hutang & .009 & .113 & .027 & .080 & .939 \\
\hline
\end{tabular}




\begin{tabular}{|l|r|r|r|r|r|}
\hline Modal & -.050 & .038 & -.447 & -227 \\
Sendiri & & & -.323 & .227 \\
\hline
\end{tabular}

Uji t dilakukan untuk mengetahui ada tidaknya pengaruh variabel bebas dengan variabel terikat secara parsil. Hasil analisis uji hipotesis antara variabel bebas total hutang $\left(\mathrm{X}_{1}\right)$ dan modal sendiri $\left(\mathrm{X}_{2}\right)$ terhadap Earning Per Share $(\mathrm{Y})$ diperoleh hasil seperti yang terdapat pada tabel 4.5.

Menghitung $t_{\text {tabel }}$ menggunakan ketentuan $\alpha=0,05$ dan $\mathrm{df}=\mathrm{n}-\mathrm{k}=10-3=7$ maka diperoleh nilai $t_{\text {tabel }}$ sebesar 1,89 Pengujian statistik $t$ dilakukan dengan membandingkan nilai $t_{\text {hitumg }}$ dan $t_{\text {tabel. }}$ Dari pengujian maka dapat dijelaskan sebagai berikut:

a. Pengujian hipotesis kedua secara parsial, total hutang $\left(\mathrm{X}_{1}\right)$

Nilai $t$ hitung variabel total hutang $\left(X_{1}\right)$ sebesar 0,080 dan $t$ tabel sebesar 1,89dari hasil perbandingan maka dapat diketahui $t$ hitung lebih kecil dari $t_{\text {tabel, }}$ maka $\mathrm{H}_{a}$ ditolak dan $\mathrm{H}_{\mathrm{o}}$ diterima artinya tidak ada pengaruh positif secara signifikan antara variabel total hutang $\left(\mathrm{X}_{1}\right)$ dan Earning Per Share $(\mathrm{Y})$ pada PT. BFI Financeyang terdaftar di Bursa Efek Indonesia (BEI) periode 2007-2016.

b. Pengujian hipotesis ketiga secara parsial, modal sendiri $\left(\mathrm{X}_{2}\right)$

Nilai $\mathrm{t}$ hitumg sebesar 1,323 dan $\mathrm{t}$ tabel sebesar 1,89 dari hasil perbandingan maka

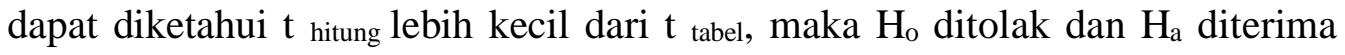
artinya ada pengaruh yang signifikan kearah negatif antara variabel modal sendiri $\left(\mathrm{X}_{2}\right)$ terhadap Earning Per Share (Y) pada PT. BFI Financeyang terdaftar di Bursa Efek Indonesia (BEI) Periode 2007-2016.

Berdasarkan hasil analisis regresi yang dilakukan dalam penelitian ini, maka dapat dijelaskan hal-hal berikut ini:

Secara simultan total hutang $\left(\mathrm{X}_{1}\right)$ dan modal sendiri $\left(\mathrm{X}_{2}\right)$ berpengaruh terhadap Earning Per Share pada PT. BFI Financeyang terdaftar di Bursa Efek Indonesia (BEI) periode 2012-2016. Ini mendukung penelitian sebelumnya yang dilakukan oleh Sari (2014) yang membuktikan bahwa Berdasarkan Hasil Uji F dapat dilihat bahwa hasil uji $\mathrm{F}$ mempunyai signifikansi sebesar 0,024 dimana sig $0,024<0,05$, hal ini berarti bahwa persamaan regresi yang diperoleh dapat diandalkan atau model yang digunakan sudah fix.

Selanjutnya pengujian secara parsial menyatakan bahwa total hutang memiliki pengaruh secara signifikan terhadap Earning Per Share pada PT. BFI Finance yang terdaftar di Bursa Efek Indonesia (BEI) periode 2007-2016,Hal ini mengandung arti bahwa setiap kenaikan modal sendiri satu satuan maka Earning Per Share akan ikut mengalami kenaikan. Hal ini sesuai dengan penelitian yang dilakukan oleh Anita (2015) membuktikan Berdasarkan hasil uji t menunjukkan bahwa variabel hutang jangka panjang dan modal sendiri berpengaruh terhadap profitabilitas (ROA), sedangkan variabel hutang jangka pendek tidak berpengaruh terhadap profitabilitas (ROA).Berdasarkan hasil Uji Koefisien Determinasi Parsial $\left(\mathrm{r}^{2}\right)$ menunjukkan bahwa hutang jangka panjang berpengaruh dominan terhadap profitabilitas (ROA) karena nilai koefisien determinasi parsialnya paling besar diantara variabel bebas lainnya.

Pengujian secara parsial menyatakan bahwa modal sendiri memiliki pengaruh negatif yang signifikan terhadap Earning Per Share pada PT. BFI Financeyang terdaftar di Bursa Efek Indonesia (BEI) periode 2012-2016 arti bahwa modal sendiri berpengaruh negatif terhadap Earning Per Share. Hal ini menunjukkan bahwa dengan penambahan total hutang sebesar $1 \%$ maka akan menurunkan Earning Per Share. 


\section{SIMPULAN}

Berdasarkan hasil pembahasan yang dilakukan pada bab sebelumnya, maka dapat dirumuskan beberapa kesimpulan sebagai berikut:

1. Berdasarkan hasil pengujian secara simultan (uji F) dapat diketahui bahwa terdapat pengaruh signifikan antara variabel total hutang $\left(\mathrm{X}_{1}\right)$ dan modal sendiri $\left(\mathrm{X}_{2}\right)$ secara bersama-sama terhadap Earning Per Share (Y). Dimana nilai $\mathrm{F}_{\text {hitung }}>\mathrm{F}_{\text {tabel }}(8.878>4,74)$.

2. Berdasarkan hasil pengujian secara parsial (uji t) dapat diketahui bahwa terdapat tidak pengaruh negatif secara signifikan antar modal sendiri $\left(\mathrm{X}_{2}\right)$ terhadap Earning Per Share (Y). Hal ini dibuktikan oleh nilai $t$ hitung $<\mathrm{t}$ tablepadavariabel modal sendiri $\left(\mathrm{X}_{2}\right)$ tidak terdapat pengaruh secara signifkan terhadap Earning Per Share (Y). Hal ini dibuktikan oleh nilai $t$ hitung $<t_{\text {tabelpada }}$ PT. BFI Finance yang terdaftar di BEI periode 2007-2016.

\section{DAFTAR PUSTAKA}

Adisetiawan, R, 2011, Pengaruh Kebijakan Modal Kerja Terhadap Return on Investment pada Industri Semen di Bursa Efek Indonesia Periode 20032010, Jurnal Ilmiah Universitas Batanghari Jambi, 11(3), 76-82

Susanti, Anita (2015), Pengaruh hutang dan modal sendiri Terhadap profitabilitas, Jurnal Ilmu dan Riset Manajemen Volume 4, Nomor 11, November 2015.

Effendi, Usman. (2014). Asas Manajemen, Jakarta: PT. Rajagrafindo Persada

Fahmi, Irham . (2014). Pengantar Manajemen Keuangan. Bandung: Alfabeta

Ghozali, Imam, (2005). Aplikasi Analisis Multivariate Dengan Program SPSS Edisi Ketiga, Badan Penerbit Universitas Diponegoro, Semarang.

Halim, Abdul. 2015. Analisis Investasi di Aset Keuangan. Jakarta. Mitra Wacana Media.

Hartono, Jogiyanto,2008, Teori Portofolio dan Analisis Investasi, Yogyakarta: BPFE.

Hery, (2015). Analisis Laporan Keuangan Pendekatan Ratio Keuangan. Edisi Pertama, Jakarta

Kasmir. (2008). Bank Analisis Laporan Keuangan.Jakarta: Rajagrafindo. persada

Mahmud M, Hanafi. Dan Abdul Halim. (2007). Analisa Laporan Keuangan. Yogyakarta: UUP YKPN

Munawir, S. (2004). Analisa Laporan Keuangan. Edisi Keempat. Cetakan Ketiga Belas. Yogyakarta. Liberty

Murni, Sri Dewi. (2015). Pengaruh Kinerja Keuangan Terhadap Laba Bersih Pada Perusahaan Ritel yang Terdaftar di BEI Tahun 2010-2013.

Riyanto, Bambang. (2001). Dasar-dasar Pembelanjaan Perusahaan, BPFE: Yogyakarta

R Sartono, Agus. (2001). Manajemen Keuangan Teori dan Aplikasi. Edisi 4, BPEE, Yogyakarta

Rivai, veithzal dan Andriana Permata Vethzal, (2006), Credit Manajemen Handbook, Edisi Pertama, Jakarta.

Sutrisno, (2008). Manajemen Keuangan Teori dan Aplikasi. Yogyakarta: BPFE

Tandelilin, Edaurdus. (2010). Manajemen Investasi dan Portofolio. Edisi Pertama, Yogyakarta: Kanisius

Umar, Husein. (2014). Metode Penelitian Untuk Skripsi dan Tesis. Jakarta: Rajawali 
Winny Hosea Dkk, (2017). Pengaruh hutang, ukuran perusahaan dan modal sendiri terhadap profitabilitas perusahaan perhotelan di indonesia dengan struktur modal sebagai variabel intervening, Ekonomi Bisnis Dan Kewirausahaan Vol. VI, No. 1 Januari 2017 